\title{
An Empirical Evidence of Performance Measurement of Audit Firms in Malaysia
}

\author{
Mohd Noor Azli Ali Khan (Corresponding Author) \\ Senior Lecturer, Dr. Faculty of Management \& Human Resource Development \\ Universiti Teknologi Malaysia, 81310 UTM Johor Bahru, Johor, MALAYSIA \\ Tel: 60-7-553-5119Ｆax: 607-5566911 E-mail: m-nazli@utm.my
}

Rohaizat Baharun (Associate Professor, Dr.)

Faculty of Management \& Human Resource Development

Universiti Teknologi Malaysia, 81310 UTM Johor Bahru, Johor, MALAYSIA

E-mail: rohaizat@utm.my

Kamaruzzaman Abdul Rahim

Faculty of Management \& Human Resource Development

Universiti Teknologi Malaysia, 81310 UTM Johor Bahru, Johor, MALAYSIA

E-mail: m-kzaman@utm.my

Norhayati Zakuan (Dr.)

Faculty of Management \& Human Resource Development

Universiti Teknologi Malaysia, 81310 UTM Johor Bahru, Johor, MALAYSIA

E-mail: norhayatimz@utm.my

Received: June 15, 2011

Accepted: July 5, 2011

doi:10.5539/ibr.v4n4p191

\begin{abstract}
This study investigates the method applied by Bumiputera audit firms to measure their performance, and the factors or variables that affect the firms' performance. Performance measurement consists of rules for assigning a value to objects or events in such a way as to represent quantities, qualities or categories of an attribute. In view of the importance of performance measurement as a planning and control mechanism, this exploratory study has been carried out. Data was collected through survey questionnaires, which were distributed by the non-probability sampling method. Among the 32 firms selected, only 29 firms measured their performance. The performance measurement approaches used by those firms are increased in the number of clients, comparison of annual income and comparison of annual profit. The result also reveals that customer factor is the main factor that affects the performance of the Bumiputera audit firms.
\end{abstract}

Keywords: Performance measurement, Professional services, Audit firms, Customer and Malaysia

\section{Introduction}

Information for performance measurement and control can serve for decision-making, planning and control, signalling, education and learning, and external communication (Simons, 2000). Performance measurement and management refer to goal definition, strategy development, benchmarking, human resource management, and feedback processes of learning organizations (Otley, 1999). Performance measurement has an important role to play in the efficient and effective management of organisations (Kennerly \& Neely, 2002). Performance measures allow companies to allocate economic responsibilities and decision rights, set performance targets, and reward target achievement (Merchant \& Van der Stede, 2007). Moreover, the adoption of new technologies and management practices have led to concerns in regards to the suitability of their existing control systems, including performance measurement system (Munir et al., 2011).

Performance measurement is an integral part of the planning and control cycle (Barnard, 1962) since long time ago and managers must have been planning and controlling the deployment of resources since the first organization was 
established (Neely, 1999). The importance of performance measurement has been recognised and many frameworks have been developed such as Performance Measurement Matrix (Keegan et al., 1989), SMART (Cross \& Lynch, 1989), Performance Measurement Questionnaire (Dixon et al., 1990), Performance Pyramid (Lynch \& Cross, 1991), Result and Determinants Framework (Fitzgerald et al., 1991), Balance Scorecard (Kaplan \& Norton, 1992), Performance Prism (Neely et al., 2002) and Comparative Business Scorecard (Kanji \& Moura, 2002). Furthermore, the Balance Scorecard is probably the best known of the raft of multi-dimensional performance measurement frameworks developed in the late 1980s and early 1990s (Bourne, 2008).

The need to measure performance in ways that are different from those used to measure productivity in manufacturing has attracted considerable research. Some studies have sought to illustrate the conceptual limitations of existing procedures for measurement of productivity of service firms (Hjern, 1990; Stanback \& Noyelle, 1990; Mellander, 1992; Gummesson, 1991, 1992, 1994; Gordon, 1996). Other studies have addressed the technical problems of productivity measurement for particular service industries and demonstrated the limitations of measures based on manufacturing paradigms for these industries (Berg, 1991; Berg et al., 1989; Bjurek et al., 1992).

Unique characteristics of professional services may limit the validity of the research in which addresses service productivity in general to productivity measurement of these industries. Professional knowledge is their core resource, and it is both the input and output in their production processes. Besides, the clients of professional service firms are other firms, organization or government departments, and their output is used as an intermediate input in the production processes of these firms or organizations. This differs from manufacturing in which its output is used as consumer product. This difference implies a different role for the client in the production process and a need for different ways to assess the output (Nachum, 1999).

Therefore, this research was conducted to investigate the practice of performance measurements of the services industry in general and in accounting and audit firms specifically. The focus of the research is on the practice of performance measurement among Bumiputera audit firms in Malaysia. The main objectives of this study are to identify the method applied by Bumiputera audit firms to measure their performance, and the factors or variables that affect the firms' performance.

The rest of this paper is structured as follows. The next section provides literature review. Section three explains the research method and data analysis, followed by the empirical results in section four. The final section discusses conclusions and provides some suggestions for future research in this area.

\section{Prior Research}

A number of academic studies have examined and presented evidence of performance measurement practices in various countries. The ways and means of accurately measuring organizational performance is perceived as being an increasingly important field of research for both organizations and academic alike (Folan \& Browne, 2005). Performance measurement is a topic which often discussed (Neely et al., 2005) and a complex issue that normally incorporates at least three different disciplines: economics, management and accounting (Tangen, 2004).

Neely et al. (2005) defined a performance measurement as the process of quantifying the efficiency and effectiveness of action. Then, interest in performance measures has grown, as evidenced by the large portion of literature investigating some aspects such as "benchmarking", "total quality" measures and "balanced scorecards" (Md. Mostaque \& Zahirul, 2002) as new performance measurement systems after many past criticisms prompted a reappraisal and development of performance systems. The increased attention to such systems by managers, consultants, and academics reflects the pressures that result from vigorous competition. This trend has forced organizations to improve their performance to survive in their environment and industries. The literature on performance measurement systems offers many examples of procedures for identifying, selecting and implementing appropriate performance measures (Neely et al., 2005). Dixon et al. (1990) suggested that by using appropriate performance measures will enable organizations to achieve their objectives. Furthermore, Folan and Browne (2005) suggested that recommendations concerning performance measurement can be divided into two core areas: (1) recommendations for performance measures, and (2) recommendations and issue for performance measurement framework and system design.

Ideally, a well developed, broad-based performance measurement system could be used to improve the organizations strategic focus (Kaplan \& Norton, 1996). According to Campbell (1991), performance can be evaluated using non-judgmental (or outcome) and judgmental measures. The non-judgmental measures use objective data that do not need abstraction or synthesis by the person collecting the data and are extern such as sales volume. The judgmental measure, however require an individual to make a judgment about the performance level of another individual or of themselves and used to measure both outcomes and behaviour. Judgmental evaluations are accomplished by collecting, weighing, ion to make statements the person being rated (Levy \& Sharma, 1993). 
According to Van De Ven and Morgan (1980 in MacDougall, 1993), they argued with regard to organizational performance that:

"Performance is a complex construct that reflects the criteria and standards used by decision makers to access the functioning of an organization. As this definition suggests, performance is a value Judgement on the result desired from the organization at different level of analysis... and... often change over time".

The purpose of performance measurement is to help guide the performance of tasks (Benham, 1981 in MacDougall, 1993). He argued that the role of the expert in the performance measurement was to help managers but not to tell them how to run their businesses. According to Dess and Robinson (1984), research that includes a consideration of organizational performance must address two issues: (1) the selection of a conceptual framework from which to define performance and identification of accuracy, and (2) available measures that operationalise performance.

Performance measure can be defined as a metric used to quantify the efficiency and/or effectiveness of an action (Neely et al, 2005). Performance measurement is a means of providing accountability to county residents, who are often more informed about municipal than county affairs (Berman \& Wang, 2000). Then Kaplan (1984) described a performance measurement system as an information system that aims to provide financial indicators in order to help management make decisions. Neely et al. (2005) measured a performance measurement system as a process of quantifying both efficiency and effectiveness of actions. In a similar element, Marshall et al. (1999) explain a performance measurement system as a development of indicators and collection of data to describe report and analyse performance. Furthermore, Simons (2000) defined a performance measurement system as formal information based routines and procedures that managers use to maintain or alter patterns in organisational activities.

There have been significant numbers of studies in performance measurement over recent decade. A considerable number of researches have been carried out relating to performance measurement, in which some of them have proposed different perspectives of performance model (eg. Lee et al., 2001; Makhamreh, 2000). In particular, different researches employed different type of performance measures (Weiner and Mahoney, 1981), thus the performance model should be interpreted with cautious. The results of testing the same set of independent variables on different types of performance measure that serves as the dependent variables may be varied. For example, in Makhamreh (2000), of the four types of performance measures (return on investment (ROI), earnings per share (EPS), stock prices and stock value) that have been tested against the independent variables, no significant effect of the independent variables have been found on ROI. As the mutual consensus on the selection of appropriate performance measure is rarely exist (Lewin \& Minton, 1986). Further, in the case of service sector, Healey and Potter (1987) suggested that performance measurement must concentrate on the actual achievement of the services offered and the accomplishment of meeting the consumer requirements.

The selection of performance measure is one issue, but yet the factors affecting performance is another issue that attracted the interest of researchers. Prior researches have approached on the possible factors from the narrower perspective to the wider perspective. In the narrower perspective studies, performance has been tested to a single or few factors. Siu (2000) found that there is relationship between marketing practices and company performance, while Lee et al. (2001) found that close business relationships (guanxi) positively affects business performance. On the contrary, in the wider perspective studies, the researchers tested a combination of factors to business or company performance. In Makhmareh (2000), nine factors that were classified under four variables (organizational, leadership, environmental and managerial) have been tested against company performance, but only organizational and leadership variables found to have significant impact on performance. The organizational variable in Makhmareh (2000) study is represented by the size of the company whereas the leadership variable is represented by debt/equity ratio and retained earnings.

Hise et al. (1983) and Flynn (2001) also study numbers of factors affecting the performance. Among the factors that affect performance are number of employees, inventory level, fixed assets, manager's years with present employer, manager's years in the same position (Hise et al., 1983), demographic, environmental, information processing, structural and decision making (Flynn, 2001). In conclusion, there is a variety of factors that might affect company performance and the effect itself might also diverge based on the performance measurement.

\section{Research Methodology}

This paper is aimed at gaining a better understanding of performance measure among the professional services organization in the context of audit firm in Malaysia. This is an exploratory study in attempt to identify the performance measurement practices among Bumiputera audit firms (the highest ethnic population in Malaysia). Like previous studies on performance measurement such as Atkinson and Brown (2001) and Nachum (1999), questionnaire distribution was used to data collection. The questionnaire is divided into two parts. Part one is about 
the firm and respondent's background. Part two is about the performance measurement practices in the firms and includes some questions which related to the possible factors that might affect the performance of the firms such as staff turnover and ability to comply to certain requirements and needs.

This study focuses on the firms which offer services in accounting, taxation, auditing and secretary in the five states in Malaysia as shown in Table 1. Overall, a total of $32 \mathrm{firms}$ were selected as the samples for this study. The questionnaires were distributed and filled during interviews with respondents, who either the owner or the manager of the firm. The advantages of interviewing respondents are that we were able (1) to provide explanation on the questionnaires to the respondents and (2) to verify on certain issues that we might miss in the questionnaire such as "Why does the firm not measure its performance?".

Data gathered from questionnaires were analysed using 'Statistical Packages for Social Sciences' (SPSS). We ran a descriptive analysis that consisted of min arithmetic and simple percentage, and statistical analysis of correlation analysis to identify the relationship between independent variables with dependent variables.

\section{Results}

This study aims to examine the performance measurement method adopted by the Bumiputera audit firms. Surprisingly, our findings reveal that of the 32 firms, only 29 firms measured their performance and the method adopted were actually not documented and formalized. Table 2 shows the majority of the Bumiputera audit firms operated their company more than five years. Three firms operated less than two years and four firms operated between two to five years.

Table 3 shows three companies never measure their performance in a year. 15 companies measure their performance one a year and 14 companies executed to measure their performance more than one for a year. Table 4 shows the 'informal' method of performance measurement practiced by the 29 firms. Surprisingly, our findings reveal that of the 32 firms, three companies never have the approach to measure the performance.

The comparison of the number of clients between financial years is the most popular method among the firms (representing $48 \%$ of the samples). This method is implied by the notion that "if the number of clients increased in the current financial year as compared to the previous financial year, then the firm's performance could be considered increased and vice versa". The same principle was also applied for the comparison of turnover and comparison of profit method. As the questionnaires were answered during face-to-face interview, we were able to verify the reason of informal practice of performance measurement in those firms. Almost all of the respondents were of the same opinion that they do not have ample time to really measure the performance of their firm due to time constraint. They also stressed that as long as they observed the increase in the number of clients or turnover or profit, they would be satisfied with their firms' performance.

The absence of any formal method of performance measurement by those firms was a drawback to our studies. However, in order to achieve the next objective of the study that is to determine the factors that affect the performance of the firms, we converted the performance measurement method practiced by the firms into a more meaningful method. Instead of comparing the number of clients, we convert the data available to us to gain the clients growth rate using the following formula: Clients growth rate is equal to number of new clients minus number of clients discontinue divide by current number of clients.

Clients growth rate is the dependent variable and being tested with several independent variables namely compliance to time budget, number of complaints from clients, compliance to customers' needs, compliance to the requirements of Malaysia Company Commissions (MCC), compliance to firms' planning and staff turnover. The results of "Pearson Correlation Analysis" show that compliance to time budget, compliance to customer needs and compliance to the MCC requirements are positively related to the clients' growth rate (see Table 5). Those factors are closely related to clients and the finding agrees with prior studies (eg. Mital and Lassar, 1998) that satisfactory services to clients or customers should be the main focus of any businesses particularly in service industry where the client factor is critical.

\section{Discussion of Findings and Recommendation}

This paper has investigated and reported on the nature of performance measurement practices among Bumiputera audit firms in Malaysia. Performance and productivity are two important aspects in business today. There are many parties interested in performance and productivity according to their own interests. The investors, the shareholders, the customers, the suppliers, the competitors or even their own staffs are also interested with firm performance and productivity. Many government agencies are also interested to find out the overall performance and productivity for many reasons. Furthermore, most companies recognize the need to use performance indices or "metrics" to help 
monitor and improve all aspects of product development, as helping to improve the accuracy of future development plans.

This is an exploratory study with a relatively small sample size. Nevertheless, the findings are broadly consistent with those presented by other researchers who have attempted to analyse the diverse range of interrelated factors associated with performance. This study suggests that client satisfaction factor influence the performance of accounting firms' owners. As mentioned previously, measurement problems are present in any study of performance and productivity. Wide variety of productivity measures has been reported in the literature. However, based on limitations of data and information about accounting and auditing service industry in Malaysia, performance was viewed as dependent upon factors representing subjective measurement by comparing the overall performance of a firm with other firms in similar size and year and objective measurement by using number of clients, income and profit. In particular, these measures were based upon nonproprietary data available to the interviewed personnel.

On the other hand, we did not suggest that only the measurements mentioned above are suitable for accounting and auditing industry or in other business or service sectors. A measurement technique that considers only one or a few of the resources used may result in limitations and potentially inaccurate performance measurements. However, by combining different measures of performance, a better understanding of accounting and auditing sector could be gained, thus enabling better decision-making for accountants or managers and owners. Furthermore, advanced management practice, using enhanced performance measurement techniques, could enable accounting and auditing managers to meet the challenges of an increasingly competitive market more effectively. Furthermore, greater attention should also be paid to the measurement of the importance of produced data which is more amenable to parametric statistical analysis. Refinements such as these were not possible in the current study because of the nature of the research, the state of knowledge at the time and space restraints on the questionnaire.

Future research could improve and extend our findings. For extending this exploratory study in future researchs it is suggested that we could include replication on other geographic regions or in the whole country, using data from other sector, using larger data sets, introducing extra variables, or using the more deeper or detailed of independent variables/external or internal environmental factors. The growing body of empirical studies in performance and productivity may offer opportunities for meta analysis. This methodology has not received much attention (Cooper, 1993). Finally, the Malaysian environment may be unique and, therefore, our findings may not be generalized in other emerging capital markets. Replications of performance measurement practice in other national settings warrant potential research extensions of this paper. Moreover, it is hoped that future research might be extended to improve on the limitations of this study, and hence add value to the research in this area of the various aspects of performance measurement.

\section{Acknowledgement}

The financial support for the authors' research from Ministry of Higher Education (MOHE), Malaysia and Research Management Center (RMC), Universiti Teknologi Malaysia, Johor Bahru, Johor, Malaysia votes no. 77972 by Short Term Research Grant (New Academic Staff with PhD) and Q.130000.2629.02J80 by Research University Grant (RUG) also appreciated.

\section{References}

Atkinson, H. and Brown, J.B. (2001). Rethinking performance measures: assessing progress in UK hotels. International Journal of Contemporary Hospitality Management. 128-135. http://dx.doi.org/10.1108/09596110110388918

Barnard, C.I. (1962). The functions of the executive. Harvard University Press, Cambridge, MA.

Berg, S.A. (1991). Mergers, efficiency and productivity growth in Norwegian banking 1984-1989. Norgers Bank Research Paper 1991/3. Oslo.

Berg, S.A., Forsund, F.R. and Jansen, E.S. (1989). Bank output measurement and the construction of best practice frontiers. Norges Bank Research Paper 1989/6. Oslo.

Berman, E. and Wang, X. (2000). Performance Measurement in U.S. Counties: Capacity for Reform. Public Administration Review. 60(5). 409-420.

Bourne, M. (2008). Performance measurement: learning from the past and projecting the future. Measuring Business Excellence, 12(4). 67-72. http://dx.doi.org/10.1108/13683040810919971

Bjurek, H., Kjulin, U. dan Gustafsson, B. (1992). Efficiency, productivity and determinants of inefficiency at public day care centers in Sweden. Proceedings of a Symposium on Productivity Concepts and Measurement Problems, Uppsala 1991. 173-87. 
Campbell, John P. (1991). Modelling the Performance Prediction Problem in Industrial and Organizational Psychology. In Handbook of Industrial and Organizational Psychology. Vol 1 CA: Consulting Psychology Press, 687-732.

Cooper, A.C. (1993). Challenges in Predicting New Firm Performance. Journal of Business Venturing. 8. 241-253. http://dx.doi.org/10.1016/0883-9026(93)90030-9

Cross, K.F. and Lynch, R.L. (1989). The SMART way to define and sustain success. National Productivity Review. 8(1). 23-33. http://dx.doi.org/10.1002/npr.4040080105

Dess, Gregory G. and Robinson Jr, Richard B. (1984). Measuring Organizational Performance in the Absence of Objective Measures: The Case of the Privately-held Firm and Conglomerate Business Unit. Management Journal. 5. 265-273.

Dixon, J.R., Nanni, A.J., and Vollmann, T.E. (1990). The New Performance Challenge - Measuring Operations For World - Class Competition. Dow Jones - Irwin, Homewood, IL.

Flynn, D. (2001). Life Cycles of New Venture Organizations: Different Factors Affecting Performance. Journal of Developmental Entrepreneurship. 6. April. 41-59.

Fitzgerald, L., Johnston, R. Brignall, T.J., Silvestro, R. \& Voss, C. (1991). Performance measurement in service businesses. Chartered Institute of Management Accountants, London.

Folan, P. and Browne, J. (2005). A review of performance measurement: Towards performance management. Computers in Industry. 56. 663-680.

Gordon, R.J. (1996). Problems in the measurement and performance of service sector productivity in the United States. NBER Working Paper no. 5519. NBER. Cambridge. MA.

Gummesson, E. (1991). Service quality - A holistic view. in Gummesson, E., Edvardsson, B. and Gustavsson, B.O. (Eds.). Service Quality, New York: Lexington Books. 52-75.

Gummesson, E. (1992). Service productivity: a blasphemous approach. Paper presented at $2^{\text {nd }}$ International Research Seminar in Service Management. France. June.

Gummesson, E. (1994). Service management: An evaluation and the future. The International Journal of Service Industry Management. 5(1). 64-78. http://dx.doi.org/10.1108/09564239410051920

Healey, M. and Potter, J. (1987). Making Performance Measurement Work for Consumer. In Performance Measurement and the Consumer. National Consumer Council. London.

Hise, R.T., Kelly, J.P., Gable, M. and McDonald, J.B. (1983). Factors Affecting the Performance of Individual Chain Store Units: An Empirical Analysis. Journal of Retailing. Summer. 59. 22-40.

Hjern, B. (1990). The private service sector: the problem of productivity development. Karlstad. CTF. Research report. 90:2.

Kanji, G.K. \& Moura, P.E. (2002). Kanji's business scorecard - quality assurance and total quality management. Total Quality Management and Business Excellence. 13(1). 13-27. http://dx.doi.org/10.1080/09544120120098537

Kaplan, R.S. (1984). The evaluation of management accounting. The Accounting Review. 56(3). 390-418.

Kaplan, R.S. and Norton, D.P. (1992). The balanced scorecard - measures that drive performance. Harvard Business Review. 70(1). 71-79.

Kaplan, R.S. and Norton, D.P. (1996), The balanced scorecard - measures that drive performance. Harvard Business Review, January-February. 71-79.

Keegan, D.P., Eiler, R.G. and Jones, C.S. (1989). Are your performance measures obsolute?. Management Accounting (USA). June. 45-50.

Kennerley, M. and Neely, A.D. (2002). A framework of the factors affecting the evolution of performance measurement systems. International Journal of Operations \& Production Management. 22(11). 1222-1245. http://dx.doi.org/10.1108/01443570210450293

Lee, Dong Jin, Pae, Jae H. and Wong, Y.H. (2001). A Model of Close Business Relationship in China (guanxi). European Journal of Marketing. 35, no1/12, 51-69.

Levy, Michael and Sharma, Arun. (1993). Relationship among measures of retail salesperson performance. Journal of the Academy of Marketing Science (Summer), 231-238. http://dx.doi.org/10.1177/0092070393213006 
Lewin, A. and Minton, J. (1986). Determining Organizational Effectiveness: Another Look and an Agenda for Research. Management Science. 32, 539-553. http://dx.doi.org/10.1287/mnsc.32.5.514

Lynch, R.L. and Cross, K.F. (1991). Measure Up: Yardsticks for Continuous Improvement. Cambridge, MA, Blackwell Publishers.

MacDougall, James Clark. (1993). Performance Contracts and Quality Management. PhD Thesis, University of Stirling.

Makhamreh, M. (2000). Corporate Performance in Jordan: A Study of the Banking Sector. The Arab Bank Review. 2(2). October. 40-48.

Marshall, M., Wray, L., Epstein, P. and Grifel, S. (1999). $21^{\text {st }}$ century community focus: better results by linking citizens, government and performance measurement. Public Management. 81(10). 12-19.

Md. Mostaque Hussain and Gunasekaran, A. (2002). Non-financial management accounting measures in Finnish financial institutions. European Business Review. 14(3). 210-229.

Mellander, E. (1992). An indirect approach to measuring productivity in private services. Proceedings of a symposium on productivity concepts and measurement problems. Uppsala 1991. 229-244.

Merchant, K.A. and Van der Stede, W. (2007). Management Control Systems: Performance Measurement, Evaluation and Incentives. Pearson/Prentice Hall, London.

Mittal, Banwari and Lassar, W.M. (1998), Why Do Customer Switch? The Dynamics of Satisfaction Versus Loyalty. The Journal of Service Marketing. 12(3). 177-194.

Munir, R., Perera, S., and Baird, K. (2011). An Analytical Framework to Examine Changes in Performance Measurement Systems within the Banking Sector. Australasian Accounting Business and Finance Journal, 5(1), 93-115.

Nachum, L. (1999). Measurement of productivity of professional services - an illustration on Swedish management consulting firms. International Journal of Operations \& Production Management. 19(9). 922-949. http://dx.doi.org/10.1108/01443579910280269

Neely, A.D. (1999). The performance measurement revolution: why now and what next?. International Journal of Operations \& Production Management. 19(2). 205-228. http://dx.doi.org/10.1108/01443579910247437

Neely, A.D., Adams, C. \& Kennerley, M. (2002). The performance prism: the scorecard for measuring and managing business success. Financial Times, Prentice-Hall: London.

Neely, A., Gregory, M. and Platts, K. (2005). Performance measurement system design: a literature review and research agenda. International Journal of Operations and Production Management. 25(12). 1228-1263. http://dx.doi.org/10.1108/01443570510633639

Otley, D. (1999). Performance management: a framework for management control systems research. Management Accounting Research, 10(4). 363-382. http://dx.doi.org/10.1006/mare.1999.0115

Simons, R. (2000). Performance Measurement Control Systems for Implementing Strategy Text Cases. Prentice Hall, Upper Saddle River, NJ.

Siu, Wai-Sum. (2000). Marketing and Company Performance of Chinese Small Firms in Hong Kong. Marketing Intelligence and Planning. 18(5), 292-307. http://dx.doi.org/10.1108/02634500010343991

Stanback, T.M. and Noyelle, T. (1990). Productivity in services: A valid measure of economic performance? in. Noyelle, T. (Ed.). Skills, Wages and Productivity in the Service Sector. Oxford: Westview Press. 215-245.

Tangen, S. (2004). Performance measurement: from philosophy to practice. International Journal of Productivity and Performance Management. 53(8). 726-737. http://dx.doi.org/10.1108/17410400410569134

Weiner, N. and Mahoney, T. (1981). A Model of Corporate Performance as a Function of Environmental, Organizational and Leadership Influences. Academy of Management Journal. 24, 453-470. http://dx.doi.org/10.2307/255568

\section{Appendix}


Table 1. Number of Respondents

\begin{tabular}{clcr}
\hline No. & State & No. of Sample & Percentage \\
\hline 1 & Penang & 2 & 6.25 \\
2 & Kelantan & 4 & 12.50 \\
3 & Johor & 8 & 25.00 \\
4 & Pahang & 8 & 25.00 \\
5 & Terengganu & 10 & 31.25 \\
\hline & Total & $\mathbf{3 2}$ & $\mathbf{1 0 0}$ \\
\hline
\end{tabular}

Table 2. Years of Operation

\begin{tabular}{lcc}
\hline Year & No. of Sample & Percentage \\
\hline Less than two years & 3 & 9 \\
Two years until five years & 4 & 12 \\
Five years until ten years & 13 & 41 \\
More than ten years & 12 & 38 \\
Total & $\mathbf{3 2}$ & $\mathbf{1 0 0}$ \\
\hline
\end{tabular}

Table 3. Frequency of Performance Measurement by Companies

\begin{tabular}{lcc}
\hline Method & No. of Sample & Percentage \\
\hline Never & 3 & 9 \\
At least one a year & 15 & 47 \\
More than one a year & 14 & 44 \\
Total & $\mathbf{3 2}$ & $\mathbf{1 0 0}$ \\
\hline
\end{tabular}

Table 4. Performance Measurement Method

\begin{tabular}{lcc}
\hline Method & No. of Sample & Percentage \\
\hline Comparison of the number of clients & 14 & 48 \\
Comparison of turnover & 7 & 24 \\
Comparison of profit & 3 & 10 \\
Others & 5 & 18 \\
Total & $\mathbf{2 9}$ & $\mathbf{1 0 0}$ \\
\hline
\end{tabular}

Table 5. Correlation Analysis

\begin{tabular}{|c|c|c|}
\hline Variables & Coefficient of Correlation & $p$-value \\
\hline Compliance to time budget & 0.513 & $0.009^{*}$ \\
\hline No. of complaints from clients & & 0.714 \\
\hline Compliance to firms' planning & & 0.127 \\
\hline Compliance to clients needs & 0.458 & $0.021 *$ \\
\hline Compliance to $\mathrm{MCC}$ requirements & 0.380 & $0.061 *$ \\
\hline Staff turnover & & 0.954 \\
\hline
\end{tabular}

\footnotetext{
* Significant at 0.10
} 